\title{
Keanekaragaman dan peran fungsional serangga Ordo Coleoptera di area reklamasi pascatambang batubara di Berau, Kalimantan Timur
}

\author{
Diversity and functional role of beetles (Order Coleoptera) in \\ reclamation area of coal post-mining in Berau, East Kalimantan
}

\author{
Gilang Aditya Rahayu ${ }^{{ }^{*}}$, Damayanti Buchori ${ }^{1}$, Dadan Hindayana ${ }^{1}$, Akhmad Rizali ${ }^{2}$ \\ ${ }^{1}$ Departemen Proteksi Tanaman, Fakultas Pertanian, Institut Pertanian Bogor. \\ Jalan Kamper, Kampus IPB Dramaga, Bogor 16680 \\ ${ }^{2}$ Jurusan Hama dan Penyakit Tumbuhan, Fakultas Pertanian, Universitas Brawijaya \\ Jalan Veteran, Malang 65145
}

(diterima Oktober 2015, disetujui Juli 2017)

\begin{abstract}
ABSTRAK
Reklamasi adalah salah satu teknik untuk memulihkan ekosistem yang rusak, dengan tujuan mengembalikan kondisi habitat, seperti atau menyerupai kondisi sebelumnya. Salah satu komponen habitat yang perlu dikembalikan adalah komunitas serangga. Penelitian ini bertujuan untuk mempelajari keanekaragaman, peranan fungsional, dan komposisi Coleoptera pada area reklamasi. Penelitian dilakukan di area reklamasi bekas tambang batubara, PT. Berau Coal di Kabupaten Berau, Kalimantan Timur. Area reklamasi terdiri atas beberapa umur revegetasi berbeda, yaitu 2, 4, 6, 8, dan 10 tahun. Pengambilan contoh dilakukan dengan melakukan pemasangan perangkap pitfall dan perangkap malaise pada transek sepanjang 100 meter untuk setiap umur revegetasi. Hasil penelitian menunjukkan bahwa keanekaragaman Coleoptera antar umur reklamasi tidak menunjukkan perbedaan. Umur reklamasi cenderung mempengaruhi perbedaan komposisi spesies dan peranan fungsional Coleoptera. Kelimpahan Coleoptera predator menunjukkan perbedaan pada umur reklamasi yang berbeda, sedangkan kelimpahan Coleoptera herbivor, detritivor dan mycophagus tidak dipengaruhi oleh umur reklamasi. Walaupun demikian, terdapat kecenderungan peningkatan kelimpahan Coleoptera dari kelompok herbivor dan detritivor dengan peningkatan umur reklamasi.
\end{abstract}

Kata kunci: Coleoptera, kekayaan spesies, kelimpahan, kumbang, peran fungsional

\begin{abstract}
Reclamation has an important role in the recovery of mined land ecosystems and is expected to restore the diversity of insects such as Coleoptera. Reclamation process can change Coleoptera diversity and formed communities new of functional groups. The objective of this research was to study the diversity, functional role, and composition of the Coleoptera in the reclamation area. This ecological research was conducted in reclamation area of PT. Berau Coal in Binungan, Berau District, East Kalimantan. Several ages of reclamation area were selected for observation i.e. 2, 4, 6,8 and 10 years and also natural forest as comparison. Insects were sampled using pitfall trap and malaise trap in a 100 meter transects for each age revegetation. The results showed that there is no difference in the diversity of Coleoptera between age of reclamation. Age of reclamation tend to affect the composition species and functional role of Coleoptera. Abundance of predatory Coleoptera show differences in different reclamation ages, while the abundance of other functional group (herbivor detritivor and mycophagus) does not seen to be influenced by age of reclamation. Nevertheless, there
\end{abstract}


is an increasing trend of Coleoptera abundance of herbivores and detritivor group with increasing age reclamation.

Key words: abundance, beetle, Coleoptera, diversity, functional group, richness

\section{PENDAHULUAN}

Kerusakan dan perubahan lingkungan sebagai akibat dari kegiatan penambangan tidak dapat dihindari. Kegiatan penambangan memberikan dampak negatif berupa kerusakan ekosistem alam dan rusaknya habitat (Cooke \& Johnson 2002). Rusaknya habitat juga mengancam keberadaan keanekaragaman hayati serangga dengan hilangnya suatu spesies (Wardle et al. 2011). Dalam upaya mengurangi hilangnya keanekaragaman hayati akibat usaha tambang, pemerintah Indonesia mewajibkan kegiatan reklamasi berupa pemulihan lahan dan manajemen lingkungan pascatambang (Peraturan Pemerintah No. 78 tahun 2010). Kegiatan reklamasi diharapkan dapat menyediakan kembali habitat bagi flora dan fauna sehingga akan mengembalikan keanekaragaman hayati daerah pascatambang dibuka.

Reklamasi adalah salah satu teknik untuk memulihkan ekosistem yang rusak, dengan tujuan mengembalikan kondisi habitat, seperti atau menyerupai kondisi sebelumnya. Salah satu komponen dari habitat yang perlu dikembalikan adalah komunitas serangga. Memulihkan komunitas serangga merupakan hal penting karena serangga berperan dalam fungsi ekosistem (Babin-Fenke \& Anand 2010). Terjadinya proses suksesi dan perubahan lingkungan dapat mengubah keanekaragaman serangga sebelumnya. Proses atau tahapan suksesi dalam kegiatan reklamasi akan mempengaruhi keanekaragaman serangga (Speight et al. 2008), seperti terjadinya perbedaan kelimpahan serangga pada umur reklamasi berbeda. Sebagai contoh kelimpahan kumbang pada tahapan suksesi awal lebih rendah dibandingkan dengan kelimpahan pada suksesi yang sudah lanjut atau hutan (Skalski \& Pośpiech 2006).

Kumbang merupakan serangga dari Ordo Coleoptera yang memiliki keanekaragaman yang tinggi dan melimpah, selain itu berperan penting dalam fungsi ekosistem (Schowalter 2011). Peran kumbang dibutuhkan dalam ekosistem karena aktivitas kumbang sebagai pemakan tanaman, 98 predator, scavenger, dan dekomposer (CSIRO 1990). Aktivitas kumbang herbivora sangat penting bagi ekosistem karena kumbang herbivora merupakan hama penting bagi tanaman dan dapat mempengaruhi keanekaragaman tanaman (Carson \& Root 1999), sedangkan kumbang predator dapat mempengaruhi populasi serangga lainnya (Schowalter 2011). Selain itu, kumbang juga banyak berperan sebagai scavenger dan dekomposer dalam proses penguraian bahan organik baik di permukaan tanah maupun di dalam tanah (Price et al. 2011).

Penelitian ini bertujuan untuk mempelajari keanekaragaman Coleoptera di area reklamasi, mempelajari hubungan kekayaan spesies Coleoptera dengan umur reklamasi, dan mempelajari komposisi peranan fungsional Coleoptera pada umur reklamasi berbeda.

\section{BAHAN DAN METODE}

\section{Lokasi penelitian}

Penelitian lapangan dilaksanakan di lahan reklamasi pascatambang batu bara di Area Binungan, PT. Berau Coal di Kecamatan Sambaliung, Kabupaten Berau, Provinsi Kalimantan Timur. Pengambilan contoh serangga dilakukan antara Juli-Agustus 2012. Identifikasi serangga dilakukan di Laboratorium Pengendalian Hayati, Departemen Proteksi Tanaman, Fakultas Pertanian, Institut Pertanian Bogor.

\section{Pengambilan contoh serangga}

Penentuan lahan contoh dilakukan berdasarkan umur penanaman atau umur revegetasi. Lahan contoh terdiri atas berbagai tingkat umur yang dapat mewakili seluruh umur area reklamasi penelitian, yaitu terdiri atas 10 tahun (dengan kode A2), 8 tahun (D4), 6 tahun (H1), 4 tahun (IPD), 2 tahun (PIT) dengan 2 ulangan pada masing-masing lahan. Pada masing-masing lahan dilakukan pengambilan sampel sebanyak 2 kali (2 ulangan). Selain itu juga, ditentukan lahan contoh berupa hutan sekunder sebagai representasi dari habitat 
alami. Setiap lahan dibuat jalur transek sepanjang $100 \mathrm{~m}$ menghadap utara-selatan untuk tempat pemasangan perangkap serangga (berdasarkan metode Majer et al. 2007).

Perangkap yang digunakan ada dua macam, yaitu perangkap jebak (pitfall trap) untuk menangkap Coleoptera di permukaan tanah dan malaise trap untuk yang terbang (Gambar 2). Perangkap pitfall yang digunakan adalah berupa gelas plastik dengan diameter $7,5 \mathrm{~cm}$ dan tinggi $10,5 \mathrm{~cm}$. Larutan yang digunakan pada perangkap pitfall berupa campuran 1 liter etilen glikol, $25 \mathrm{ml}$ sabun cair, dan 4 liter air. Perangkap pitfall dipasang sebanyak 10 buah dengan jarak $10 \mathrm{~m}$ antar masing-masing perangkap pitfall dan diaplikasikan selama 6 hari di lapangan. Perangkap malaise sebanyak 2 unit dengan tinggi $\pm 2 \mathrm{~m}$ dan memiliki 4 sisi dengan jarak $60 \mathrm{~m}$ antar perangkap malaise kemudian diaplikasikan selama 4 hari di lapangan.

Spesimen serangga Coleoptera yang diperoleh dimasukkan ke dalam botol film berisi alkohol 70\% kemudian diberi label kode lahan dan perangkap. Identifikasi dan disortasi hingga tingkat famili dan morfospesies mengacu pada kunci identifikasi serangga pada Borror et al. (1996) dan CSIRO insect of Australia (1998).

\section{Analisis data}

Data yang diperoleh dianalisis menggunakan indeks Shanon-Wiener untuk mengetahui keanekaragaman serangga dan nilai kemerataan (Magurran 1988). Untuk mengetahui hubungan kekayaan dan kelimpahan spesies dengan umur reklamasi dianalisis dengan menggunakan analisis korelasi. Proporsi peran fungsional Coleoptera dianalisis menggunakan analisis ragam (ANOVA). Perbedaan komposisi spesies antar umur reklamasi dianalisis dengan menggunakan analysis of similarity (ANOSIM), sedangkan ordinasi non metric multidimensional scaling (NMDS) digunakan untuk menampilkan perbedaan komposisi spesies Coleoptera antar umur reklamasi berbeda berdasarkan indeks Bray-Curtis. Seluruh analisis

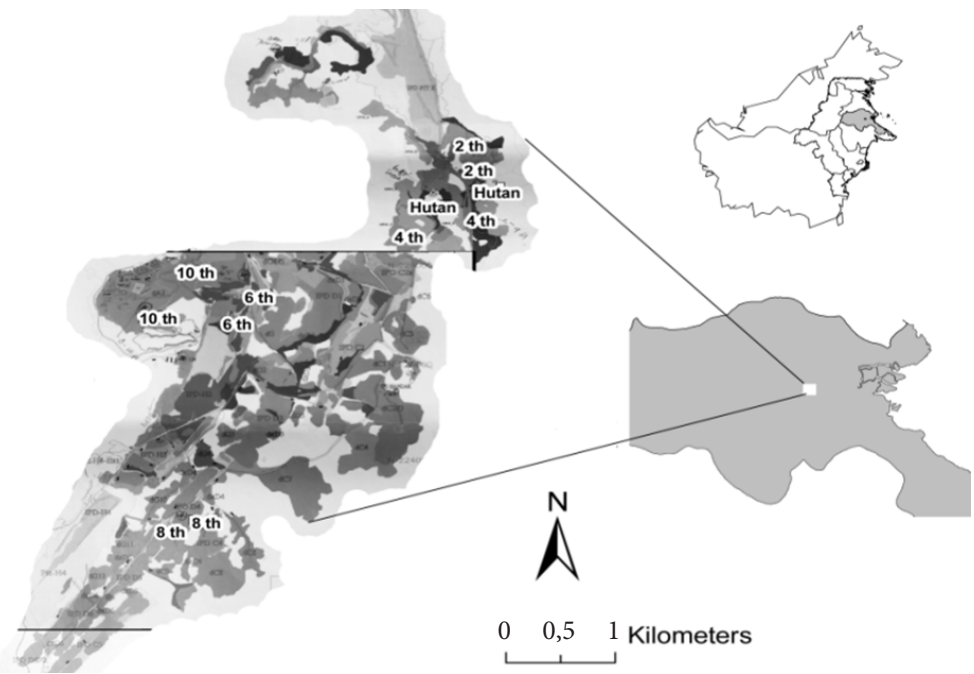

Gambar 1. Peta dan lokasi lahan-lahan contoh area reklamasi.

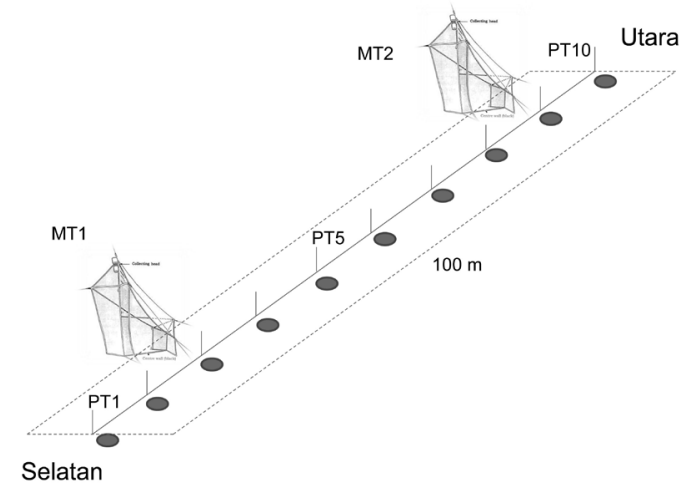

Gambar 2. Skema pemasangan perangkap serangga. MT: perangkap malaise; PT: perangkap pitfall. 
dilakukan dengan menggunakan perangkat lunak $R$ Statistic (R Development Core Team 2015).

HASIL

\section{Keanekaragaman Coleoptera}

Total morfospesies Coleoptera yang ditemukan dari hasil pemerangkapan di area reklamasi berjumlah 97 spesies dari 33 famili dengan 220 individu kumbang (Tabel 1). Hasil analisis Anova kelimpahan $\left(\mathrm{F}_{5,55}=0,278 ; \mathrm{P}=0,923\right)$ dan kekayaan $\left(\mathrm{F}_{5,55}=0,791 ; \mathrm{P}=0,562\right)$ tidak berbeda nyata antar umur reklamasi. Begitupula hasil analisis korelasi menunjukkan bahwa tidak ada korelasi antar umur reklamasi dengan kelimpahan $(\mathrm{r}=0,00007, \mathrm{P}=$ $0,97)$ dan kekayaan spesies Coleoptera $(r=0,094$, $\mathrm{P}=0,33)$ juga menunjukkan bahwa umur tidak mempengaruhi kekayaan spesies yang ada.

Nilai keanekaragaman Coleoptera antar umur reklamasi baik yang umur muda maupun tua memiliki nilai $<3$ kecuali lahan reklamasi 4

Tabel 1. Famili, morfospesies, dan peranan fungsional kumbang di lahan reklamasi

\begin{tabular}{|c|c|c|c|c|c|c|c|c|c|c|c|c|c|c|}
\hline \multirow{3}{*}{ Famili } & \multirow{3}{*}{ Morfospesies } & \multirow{3}{*}{ Peranan } & \multicolumn{12}{|c|}{ Umur lahan reklamasi } \\
\hline & & & \multicolumn{2}{|c|}{2} & \multicolumn{2}{|c|}{4} & \multicolumn{2}{|c|}{6} & \multicolumn{2}{|c|}{8} & \multicolumn{2}{|c|}{10} & \multicolumn{2}{|c|}{ Hutan } \\
\hline & & & PT & MT & $\mathrm{PT}$ & MT & $\mathrm{PT}$ & MT & $\mathrm{PT}$ & MT & PT & MT & $\mathrm{PT}$ & MT \\
\hline \multirow[t]{4}{*}{ Anthicidae } & Anthicidae sp.01 & Predator & & & & & 1 & & & & & & & \\
\hline & Anthicidae sp.02 & Predator & & & & & & & & & & 1 & & \\
\hline & Anthicidae sp.03 & Predator & & & 1 & & & & & & 1 & & & \\
\hline & Anthicidae sp.04 & Predator & & & & & & & & & 1 & & & \\
\hline Anthribidae & Anthribidae sp.02 & Herbivor & & & & & & & & 1 & & & & \\
\hline Biphyllidae & Biphyllidae sp.01 & Herbivor & & & & & & & & 1 & & & & \\
\hline Bruschidae & Bruschidae sp.01 & Herbivor & & & & & 1 & & & & & & & \\
\hline \multirow[t]{3}{*}{ Buprestidae } & Buprestidae sp.01 & Herbivor & & & & & & 1 & & & & & & \\
\hline & Buprestidae sp.02 & Herbivor & & & & & & & & 1 & & & & \\
\hline & Buprestidae sp.03 & Herbivor & & & & & & & & 1 & & & & \\
\hline \multirow[t]{3}{*}{ Carabidae } & Carabidae sp.03 & Predator & 1 & & & & & & & & & & & \\
\hline & Carabidae sp.06 & Predator & & & & & 1 & & & & & & & \\
\hline & Carabidae sp.07 & Predator & & & & & & & & & 1 & & & \\
\hline Cerambycidae & Cerambycidae sp.04 & Herbivor & & & & & & & & & & & & 1 \\
\hline \multirow[t]{9}{*}{ Chrysomellidae } & Chrysomellidae sp.01 & Herbivor & & & 1 & & & & & & & & & \\
\hline & Chrysomellidae sp.02 & Herbivor & & & & & & & 1 & & & & & \\
\hline & Chrysomellidae sp.03 & Herbivor & & & & & & & & 1 & & & & \\
\hline & Chrysomellidae sp.04 & Herbivor & & & & & & 1 & & & & & & \\
\hline & Chrysomellidae sp.07 & Herbivor & & & & & & 2 & & & & & & \\
\hline & Chrysomellidae sp.09 & Herbivor & & & & & & & & & & 1 & & \\
\hline & Chrysomellidae sp.10 & Herbivor & & & & & & 2 & & & & 1 & & \\
\hline & Chrysomellidae sp.11 & Herbivor & 1 & & & & & & & & & & & \\
\hline & Chrysomellidae sp.12 & Herbivor & & 1 & & & & & & & & & & 1 \\
\hline \multirow[t]{2}{*}{ Cicindellidae } & Cicindellidae sp.02 & Predator & 3 & & 1 & & & & & & & & & \\
\hline & Cicindellidae sp.03 & Predator & 7 & & & & & & & & & & & 1 \\
\hline Clambidae & Clambidae sp.01 & Detritivor & & & & & & & & & 7 & & & \\
\hline \multirow[t]{5}{*}{ Coccinellidae } & Coccinellidae sp.01 & Predator & & & & 1 & & & & & & & & \\
\hline & Coccinellidae sp.04 & Predator & & & & & & 1 & & & & & & \\
\hline & Coccinellidae sp.05 & Herbivor & & & & & & 4 & & & & & & \\
\hline & Coccinellidae sp.06 & Predator & & & & & & & & & & 1 & & \\
\hline & Coccinellidae sp.07 & Predator & & & & & & & & & & & 1 & \\
\hline
\end{tabular}

PT: perangkap pitfall; MT: perangkap malaise 
Lanjutan Tabel 1.

\begin{tabular}{|c|c|c|c|c|c|c|c|c|c|c|c|c|c|c|}
\hline \multirow{3}{*}{ Famili } & \multirow{3}{*}{ Morfospesies } & \multirow{3}{*}{ Peranan } & \multicolumn{12}{|c|}{ Umur lahan reklamasi } \\
\hline & & & \multicolumn{2}{|c|}{2} & \multicolumn{2}{|c|}{4} & \multicolumn{2}{|c|}{6} & \multicolumn{2}{|c|}{8} & \multicolumn{2}{|c|}{10} & \multicolumn{2}{|c|}{ Hutan } \\
\hline & & & PT & MT & PT & MT & PT & MT & PT & MT & PT & MT & PT & MT \\
\hline \multirow[t]{4}{*}{ Coleoptera } & Coleoptera sp.01 & & & & & & & & & & 1 & & & \\
\hline & Coleoptera sp.02 & & & & & & & & & & 1 & & & \\
\hline & Coleoptera sp.03 & & 1 & & & & & & & & & & & \\
\hline & Coleoptera sp.09 & & & & & & & & 1 & & & & & \\
\hline \multirow[t]{3}{*}{ Colydiidae } & Colydiidae sp.01 & Predator & & & & & & & 1 & & & & & \\
\hline & Colydiidae sp.02 & Predator & & & & & 1 & & & & & & 1 & \\
\hline & Colydiidae sp.03 & Predator & & & 1 & & & & & & & & & \\
\hline \multirow[t]{2}{*}{ Corylophidae } & Corylophidae sp.01 & Mychopagus & & & & 1 & & & & & & & & \\
\hline & Corylophidae sp.02 & Mychopagus & & & 1 & & & & & & & & & \\
\hline \multirow[t]{3}{*}{ Curculionidae } & Curculionidae sp.02 & Herbivor & & & & 1 & & & & & & & & \\
\hline & Curculionidae sp.03 & Herbivor & & & & & & 3 & & 7 & & & & \\
\hline & Curculionidae sp.04 & Herbivor & & 1 & & & & & & & & & & \\
\hline Dryopidae & Dryopidae sp.01 & Detritivor & & & & & & & & 1 & & & & \\
\hline \multirow[t]{2}{*}{ Elateridae } & Elateridae sp.02 & Herbivor & 4 & & 2 & & & & & & & & & \\
\hline & Elateridae sp.03 & Herbivor & & & 1 & & & & & & & & & \\
\hline \multirow[t]{2}{*}{ Lampyridae } & Lampyridae sp.02 & Predator & & & & 1 & & & & & & & & \\
\hline & Lampyridae sp.03 & Predator & & & & & & & & & & 3 & & \\
\hline Limnichidae & Limnichidae sp.01 & Herbivor & & & & 1 & & & & & & & & \\
\hline Lycidae & Lycidae sp.01 & Detritivor & & & & & & 1 & & & & & & \\
\hline Melyridae & Melyridae sp.01 & Predator & & & & 1 & & & & & & & & \\
\hline Monommidae & Monommidae sp.01 & Detritivor & & & & & & & & & & 1 & & \\
\hline Mordellidae & Mordellidae sp.04 & Herbivor & & 1 & & & & & & & & & & 1 \\
\hline \multirow[t]{4}{*}{ Nitidullidae } & Nitidullidae sp.04 & Mycophagus & & & & & 2 & & & & 1 & & & \\
\hline & Nitidullidae sp.05 & Mycophagus & & 1 & & & & & & & & & & \\
\hline & Nitidullidae sp.06 & Mycophagus & & & 1 & & & & & & & & & \\
\hline & Nitidullidae sp.07 & Mycophagus & & & & & 1 & & & & & & & \\
\hline Phalacridae & Phalacridae sp.01 & Mycophagus & & 1 & & 1 & & & & & & & & \\
\hline Ptillidae & Ptillidae sp.01 & Detritivor & & & & & & & 1 & & & & 3 & \\
\hline \multirow[t]{2}{*}{ Scarabaeidae } & Scarabaeidae sp.01 & Herbivor & 1 & & & & 1 & 1 & & & & & & \\
\hline & Scarabaeidae sp.05 & Herbivor & & & & & & & & & 1 & & 1 & \\
\hline \multirow[t]{3}{*}{ Scirtidae } & Scirtidae sp.01 & Detritivor & & & & & & & & & & 1 & & 1 \\
\hline & Scirtidae sp.02 & Detritivor & & & & 1 & & & & & & & & \\
\hline & Scirtidae sp.04 & Detritivor & & & & 1 & & & & & & & & \\
\hline Scolytidae & Scolytidae sp.01 & Myophagus & & & & & & & & & & & 1 & \\
\hline & Scolytidae sp.03 & Myophagus & & & & & & & & & 1 & & & \\
\hline & Scolytidae sp.05 & Myophagus & & & & & & & & & 1 & & & \\
\hline & Scolytidae sp.06 & Myophagus & & & & & & & 1 & & & & & \\
\hline & Scolytidae sp. 12 & Myophagus & & & & & & & & & & 1 & & \\
\hline Scydmaenidae & Scydmaenidae sp.01 & Predator & & & & & & & & & 1 & & 1 & \\
\hline & Scydmaenidae sp.02 & Predator & & & 1 & & & & & & 13 & & & \\
\hline Silvanidae & Silvanidae sp.01 & Detritivor & & & & & & & 1 & & & & & \\
\hline Sphindidae & Sphindidae sp.01 & Detritivor & & & & & & & & & & & & 1 \\
\hline
\end{tabular}

PT: perangkap pitfall; MT: perangkap malaise 
Lanjutan Tabel 1.

\begin{tabular}{|c|c|c|c|c|c|c|c|c|c|c|c|c|c|c|}
\hline \multirow{3}{*}{ Famili } & \multirow{3}{*}{ Morfospesies } & \multirow{3}{*}{ Peranan } & \multicolumn{12}{|c|}{ Umur lahan reklamasi } \\
\hline & & & \multicolumn{2}{|c|}{2} & \multicolumn{2}{|c|}{4} & \multicolumn{2}{|c|}{6} & \multicolumn{2}{|c|}{8} & \multicolumn{2}{|c|}{10} & \multicolumn{2}{|c|}{ Hutan } \\
\hline & & & PT & MT & $\mathrm{PT}$ & MT & $\mathrm{PT}$ & MT & PT & MT & $\mathrm{PT}$ & MT & PT & MT \\
\hline \multirow[t]{19}{*}{ Staphylinidae } & Staphylinidae sp.01 & Predator & & & & & 1 & & & & & & & \\
\hline & Staphylinidae sp.02 & Predator & & & 1 & & & & & & & & 1 & \\
\hline & Staphylinidae sp.03 & Predator & & & & & 2 & & & & & & & \\
\hline & Staphylinidae sp.04 & Predator & 1 & & & & & & & & & & 5 & \\
\hline & Staphylinidae sp.05 & Predator & 15 & & 1 & & & & & & & & & \\
\hline & Staphylinidae sp.06 & Predator & 15 & & 3 & & 1 & & 1 & & & & & \\
\hline & Staphylinidae sp.07 & Predator & & & & & 1 & & & & & & 1 & \\
\hline & Staphylinidae sp.09 & Predator & & & 3 & & & & & & 1 & & & \\
\hline & Staphylinidae sp.10 & Predator & & & & & & & 1 & & & & 1 & \\
\hline & Staphylinidae sp.13 & Predator & & & & & & & & & & & 3 & \\
\hline & Staphylinidae sp.15 & Predator & & & & & & & 1 & & 1 & & 1 & \\
\hline & Staphylinidae sp.16 & Predator & & & & & & & & & & & 1 & \\
\hline & Staphylinidae sp.19 & Predator & & & & & & & & & & & 4 & \\
\hline & Staphylinidae sp.21 & Predator & & & & & & & & & & & 1 & \\
\hline & Staphylinidae sp.22 & Predator & & & & & & & 1 & & & & & 2 \\
\hline & Staphylinidae sp.23 & Predator & & & & & & & & & 1 & & 1 & \\
\hline & Staphylinidae sp.24 & Predator & & & & & & & & & & & 1 & \\
\hline & Staphylinidae sp. 25 & Predator & & & & & & & & & 1 & & 1 & \\
\hline & Staphylinidae sp.26 & Predator & & & & & & & & & 1 & & & \\
\hline \multirow[t]{5}{*}{ Tenebrionidae } & Tenebrionidae sp.01 & Detritivor & & & & & & & & & & & & 1 \\
\hline & Tenebrionidae sp.02 & Detritivor & & & 1 & & & & & & & & & \\
\hline & Tenebrionidae sp.03 & Detritivor & & & 1 & & & & & & & & & \\
\hline & Tenebrionidae sp.04 & Detritivor & & & & & 1 & & & & & & & \\
\hline & Tenebrionidae sp.05 & Detritivor & & & & & & & & & & & 1 & \\
\hline Total & & & 49 & 5 & 20 & 9 & 14 & 16 & 10 & 13 & 35 & 10 & 30 & 9 \\
\hline \multicolumn{3}{|c|}{ Total yang tertangkap pitfall trap } & \multicolumn{12}{|c|}{158} \\
\hline \multicolumn{3}{|c|}{ Total yang tertangkap malaise trap } & \multicolumn{12}{|c|}{62} \\
\hline
\end{tabular}

PT: perangkap pitfall; MT: perangkap malaise

tahun dan hutan (Tabel 2). Hal ini menunjukkan keanekaragaman Coleoptera di seluruh umur reklamasi masih tergolong sedang yang memperlihatkan kondisi ekosistem masih belum stabil. Walaupun demikian, kemerataan spesies di lahan reklamasi mendekati dengan keadaan hutan. Distribusi spesies sangat merata dan dominasi spesies tidak terjadi, akan tetapi pada reklamasi umur 2 tahun mengindikasikan masih terjadinya dominasi spesies (Tabel 1).

\section{Peran fungsional Coleoptera}

Peran fungsional Coleoptera dikelompokan menjadi 4 kelompok, yaitu predator, herbivora, mycophagus (pemakan fungi), dan detritivor 102 (pemakan bahan organik dan scavenger). Pemerangkapan Coleoptera berdasarkan peran memperlihatkan bahwa masing-masing umur reklamasi memiliki proporsi dan komposisi peran fungsional yang berbeda.

Hasil penelitian menunjukkan bahwa kelimpahan Coleoptera predator $\left(\mathrm{F}_{5,54}=2,886\right.$; $\mathrm{P}=0,023)$ berbeda nyata antar umur reklamasi, sedangkan Coleoptera herbivor $\left(\mathrm{F}_{5,54}=0,827\right.$; $\mathrm{P}=0,536)$, detritivor $\left(\mathrm{F}_{5,54}=1,103 ; \mathrm{P}=0,371\right)$ dan mycophagus $\left(\mathrm{F}_{5,54}=0,901 ; \mathrm{P}=0,488\right)$ tidak berbeda nyata. Coleoptera predator melimpah pada umur reklamasi muda (2-4 tahun) kemudian melimpah lagi diumur reklamasi tertua (10 tahun) dan hutan (Gambar 3). Hal tersebut tampak dari 
keberadaan Famili Carabidae, Cicindelidae, dan Staphylinidae pada umur tersebut. Kemudian pada lahan reklamasi umur 10 tahun dan hutan, Coleoptera predator meningkat dari segi jenis terutama dari Famili Staphilinidae.

Kelimpahan Coleoptera hebivora walau tidak berbeda nyata antar umur reklamasi, kelimpahannya meningkat pada lahan reklamasi berumur 6 hingga 8 tahun (Gambar 3). Covercrop yang lebat dan pohon pioneer telah tumbuh tinggi di lahan reklamasi umur 6 tahun dan 8 tahun mendukung berkembangnya koloni Coleoptera herbivora. Kumbang yang habitatnya di semak-semak atau cover-crop, seperti Famili Chrysomelidae dan Coccinellidae banyak ditemukan di umur reklamasi tersebut. Selain itu, juga ditemukan juga Famili Budprestidae yang habitatnya pada pohon kayu juga ditemukan di reklamasi umur 6 tahun dan 8 tahun. Namun, pada reklamasi umur 10 tahun Coleoptera herbivora kembali rendah karena predator kembali melimpah (Gambar 3). Coleoptera detritivor keberadaannya ditemukan ketika reklamasi berumur 4 hingga 10 tahun dan hutan (Gambar 3). Kelimpahan detritivor ditemukan ketika umur reklamasi bertambah tua dan keberadaannya tidak ditemukan pada lahan yang tidak berserasah, seperti lahan reklamasi berumur 2 tahun.

\section{Komposisi spesies Coleoptera}

Hasil ANOSIM menunjukkan bahwa komposisi spesies Coleoptera berbeda nyata antar umur reklamasi $(\mathrm{R}=0,625 ; \mathrm{P}=0,003)$. Hal ini menunjukkan bahwa masing-masing umur reklamasi memiliki komposisi spesies Coleoptera yang berbeda. Berdasarkan hasil NMDS juga mengindikasikan adanya pola komposisi spesies antar umur reklamasi, seperti komposisi spesies reklamasi umur muda (2-4 tahun) terlihat terpisah dengan komposisi spesies reklamasi umur sedang hingga tertua (6-10 tahun) (Gambar 4). Selain itu, terlihat pola komposisi spesies reklamasi umur 6 tahun keatas lebih mendekati komposisi spesies di hutan.

\section{PEMBAHASAN}

Bertambahnya umur lahan reklamasi akan menambah kanopi pohon dan serasah sehingga mengubah mikrohabitat yang ada sebelumnya. Berubahnya mikrohabitat dapat memengaruhi

Tabel 2. Nilai keanekaragaman indeks Shannon-Wiener pada setiap umur reklamasi

\begin{tabular}{lccccc}
\hline Umur & Jumlah famili & Jumlah spesies & Jumlah individu & H & E \\
\hline 2 & 11 & 15 & 54 & 2,069 & 0,764 \\
4 & 17 & 24 & 29 & 3,092 & 0,973 \\
6 & 13 & 21 & 30 & 2,925 & 0,961 \\
8 & 12 & 19 & 23 & 2,674 & 0,908 \\
10 & 14 & 25 & 45 & 2,690 & 0,836 \\
Hutan & 14 & 27 & 39 & 3,110 & 0,944 \\
\hline
\end{tabular}

E: nilai kemerataan spesies; H: nilai keanekaragaman alpha Shanon-Wiener.

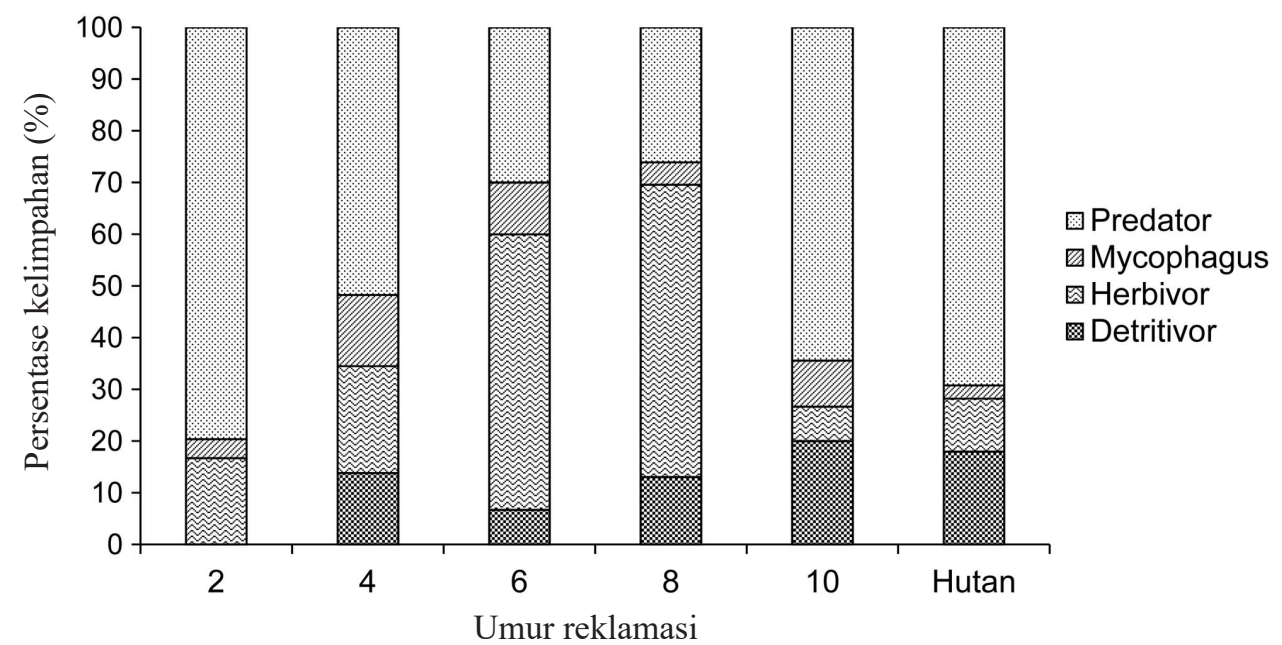

Gambar 3. Proposi kelimpahan Coleoptera berdasarkan peran fungsionalnya di lahan reklamasi. 


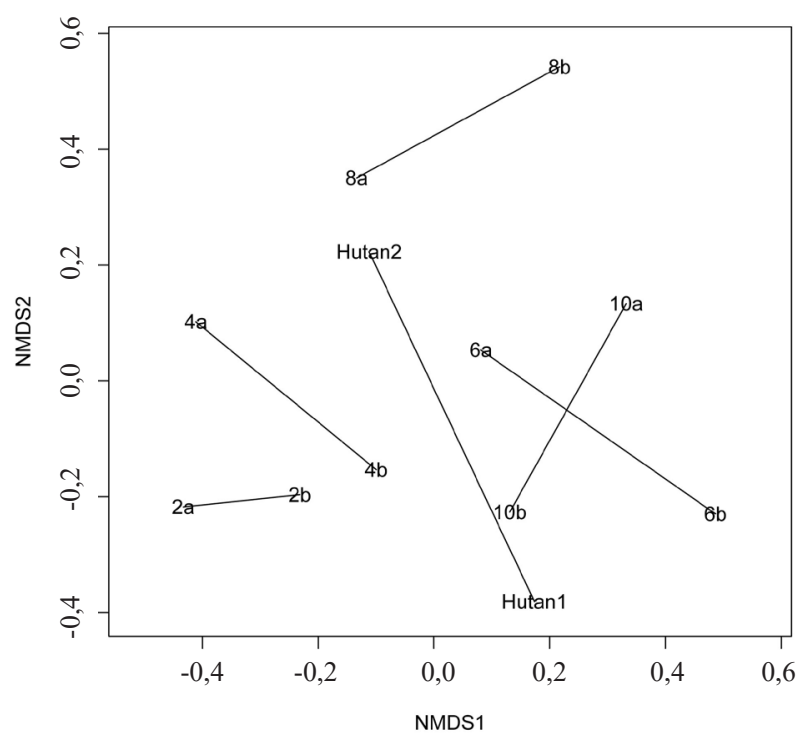

Gambar 4. Komposisi spesies Coleoptera berdasarkan hasil analisis NMDS, stress: 0,127. Garis menunjukkan reklamasi umur yang sama (plot).

kelimpahan, kekayaan spesies kumbang serta komunitasnya (Peace \& Venier 2006). Namun, hasil penelitian ini tidak menunjukkan ada pengaruh bertambahnya umur reklamasi terhadap kelimpahan maupun kekayaan Coleoptera. Dalam penelitian serupa menunjukkan bahwa kekayaan Coleoptera tidak berbeda nyata pada umur lahan yang berbeda, hal tersebut dapat disebabkan oleh proses suksesi yang lambat atau komunitas lahan yang sama antar umur yang berbeda (Skalski \& Pośpiech 2006), seperti penanaman pohon pioneer yang sama pada lahan reklamasi.

Kelimpahan dan kekayaan Coleoptera tidak berkorelasi dengan umur reklamasi begitupula dengan nilai keanekaragaman antar umur reklamasi juga masih masih kurang dari nilai 3. Hal tersebut menunjukkan adanya tekanan ekologis yang terjadi (Restu 2002) sehingga keanekaragaman Coleoptera di area reklamasi masih belum sepenuhnya stabil, seperti di lahan hutan. Dalam penelitian Riley \& Browne (2011), nilai keanekaragaman area reklamasi antara lahan muda dan lahan umur tua memiliki perbedaan yang nyata, namun dalam penelitian ini keanekaragaman antar umur reklamasi tidak berbeda nyata. Hal ini dapat disebabkan karena pengambilan sampel yang dilakukan pada lahan reklamasi yang memiliki rentang umur yang masih berdekatan sehingga tipe dan struktur vegetasi antar lahan reklamasi masih tergolong sama. Webb et al. (1999), menyatakan bahwa tipe dan struktur vegetasi suatu area dapat mempengaruhi keberadaan spesies di area tersebut.
Perbedaan umur reklamasi tidak memperlihatkan perbedaan yang nyata maupun korelasi dengan kelimpahan dan kekayaan Coleoptera, namun umur reklamasi lebih memengaruhi peranan fungsional Coleoptera. Proporsi dan komposisi peran fungsional Coleoptera akan semakin kompleks seiring dengan bertambahnya umur reklamasi. Lahan muda didominasi oleh Coleoptera predator dibandingkan herbivora. Coleoptera predator, seperti Famili Carabidae dan Cicindelidae dilaporkan melimpah di lahan muda atau lahan terbuka (Riley \& Browne 2011). Coleoptera predator, seperti Carabidae dapat ditemukan pada lahan awal suksesi (New 1997). Famili ini juga dapat ditemukan di lahan muda dan mudah tertangkap di perangkap pitfall karena famili ini merupakan predator yang hidup dan aktif mencari mangsa di permukaan tanah (CSIRO 1991). Proporsi predator juga melimpah pada lahan yang memiliki kanopi yang tertutup (Schowalter 2011), seperti reklamasi tua dan hutan. Penelitian Susilo et al. (2009) menunjukkan bahwa hutan memiliki kelimpahan dan kekayaan Coleoptera predator yang tinggi, hal ini diduga karena proporsi hebivora atau mangsa yang rendah.

Vegetasi seperti rerumputan dan tanaman herba meningkat kelimpahannya pada reklamasi sedang ( $>4$ tahun). Meningkatnya vegetasi menyebabkan sumberdaya herbivora melimpah sehingga proporsi herbivora juga meningkat. Kielhorn et al. (1999) menyimpulkan bahwa adanya korelasi positif antara jumlah vegetasi serta jumlah Coleoptera tanah. Menurut Brown (1985), 
vegetasi mendukung siklus hidup herbivora, selain itu serangga yang berasosiasi dengan tanaman ditemukan ketika reklamasi berumur 4 tahun keatas. Hal tersebut didukung juga oleh penelitian Skalski \& Pośpiech (2006) yang menunjukkan bahwa Coleoptera hebivora melimpah dan meningkat pada reklamasi berumur muda ke umur reklamasi sedang.

Coleoptera herbivora masih ditemukan di reklamasi muda, namun Coleoptera detritivor tidak ditemukan. Kumbang scavenger atau detritivor, seperti Tenebrionidae hidup pada habitat yang memiliki banyak bahan organik karena banyak berperan dalam menguraikan bahan organik (Susilo et al. 2009). Adanya bahan organik diketahui dapat meningkatkan jumlah kumbang tanah hingga lebih dari $200 \%$ (Kielhorn et al. 1999). Coleoptera detritivor dari hasil penelitian menunjukkan umumnya mulai berkoloni pada suksesi sudah lanjut, seperti umur reklamasi yang sudah tua dan hutan (Schowalter 2011). Berdasarkan komposisi Coleoptera yang ditemukan, diketahui bahwa peluang keberhasilan serta kecepatan suksesi di area penelitian sangat bergantung kepada banyak faktor, seperti tipe dan struktur vegetasi, keberadaan bahan organik yang merupakan sumber daya bagi Coleoptera.

Komposisi morfospesies Coleoptera memperlihatkan diskriminasi antar umur reklamasi terutama pada umur reklamasi muda dengan umur reklamasi tua. Hal tersebut sesuai dengan harapan teori dasar suksesi bahwa terdapat komposisi spesies yang berbeda pada umur reklamasi muda, umur tua, dan hutan (Gollan et al. 2011). Konsep dasar suksesi merupakan proses berkolonisasi kembali organisme di suatu lahan, seperti lahan reklamasi. Proses suksesi ini akan mengubah serta menggantikan suatu spesies dan asosiasi diantara spesies lainnya seiring berjalannya waktu (Young et al. 2001). Bertambah waktu atau umur lahan maka komposisi spesies Coleoptera akan bertambah atau tergantikan oleh spesies lain.

\section{KESIMPULAN}

Keanekaragaman antar umur reklamasi tidak ada perbedaan. Kelimpahan dan kekayaan spesies Coleoptera tidak berkorelasi dengan pertambahan umur reklamasi. Keanekaragaman di area reklamasi masih menuju ekosistem yang stabil dan masih terganggu oleh tekanan ekologis. Pertambahan umur reklamasi cenderung mempengaruhi peran fungsional Coleoptera dan komposisi spesies Coleoptera yang ada. Coleoptera predator pada umur reklamasi muda mendominasi, sedangkan herbivora dan detritivor mulai meningkat pada umur reklamasi sedang hingga tua. Komposisi spesies Coleoptera reklamasi tua lebih mendekati komposisi spesies hutan dibandingkan dengan komposisi spesies reklamasi muda.

\section{UCAPAN TERIMA KASIH}

Kami mengucapkan terima kasih kepada Southeast Asia Regional Centre for Tropical Biology (SEAMEO BIOTROP) dan PT. Berau Coal sebagai sponsor penelitian. Terima kasih kepada Departemen Proteksi Tanaman, Fakultas Pertanian, Institut Pertanian Bogor, Heri Tabadepu SP. dari Peka Indonesia. Laboratorium Pengendalian Hayati Adha Sari, dan Tim identifikasi (Rizki Nazareta, Rado, Lena dan Samsi).

\section{DAFTAR PUSTAKA}

Bradshaw AD. 1983. The reconstruction of ecosystems. Journal of Applied Ecology 20:1-17. doi: https://doi.org/10.2307/2403372.

BrownVK. 1985. Insect herbivores and plant succession. Oikos 44:17-22. doi: https://doi. org/10.2307/3544037.

Babin-Fenke J, Anand M. 2010. Terrestrial insect communities and the restoration of an industrially perturbed landscape: Assessing success and surrogacy. Restoration Ecology 18:73-84. doi: https://doi.org/10.1111/j.1526100X.2010.00665.x.

Borror D, Triplehorn CH, Johnson NF. 1996. An Introduction to the Study of Insects, $6^{\text {th }}$ ed. Ohio: Saunders College Publishing.

Carson WP, Root RB. 1999. Top-down effects of insect herbivores during early succession: influence on biomass and plant dominance. Oecologia 121:260-272. doi: https://doi. org/10.1007/s004420050928. 
Cooke JA, Johnson MS. 2002. Ecological restoration of land with particular reference to the mining of metals and industrial minerals: A review of theory and practice. Environmental Technology Reviews 10:41-71. doi: https://doi.org/10.1139/ a01-014.

CSIRO. 1991. The Insects of AustraliaA Textbook for Students and Research Workers Vol I \& II. Division of Entomology. Carlton Victoria: Melbourne University Press.

Gollan JR, de Bruyn LL, Reid N, Smith D, Wilkie L. 2011. Can ants be used as ecological indicators of restoration progress in dynamic environments? A case study in a revegetated riparian zone. Ecological Indicators 11:1517-1525. doi: https://doi.org/10.1016/j.ecolind.2009.09.007.

Kielhorn KH, Keplin B, Hüttl RF. 1999. Ground beetle communities on reclaimed mine spoil: Effects of organic matter application and revegetation. Plant and Soil 213:117-125. doi: https://doi.org/10.1023/A:1004508317091.

Magurran AE. 1988. Ecological Diversity and Its Measurement. London: Chapman and Hall. doi: https://doi.org/10.1007/978-94-015-7358-0.

Majer JD, Orabi G, Bisevac L. 2007. Ants (Hymenoptera: Formicidae) pass the bioindicator scorecard. Myrmecological News 10:69-76.

New TR. 1991. Insect as Predator. Sydney: New South Wales University Press.

Peraturan Pemerintah Indonesia. 2010. Peraturan Pemerintah Republik Indonesia Nomor 78 Tahun 2010 tentang: Reklamasi dan Pasca Tambang. Jakarta: Republik Indonesia.

Pearce JL, Venier LA. 2006. The use of ground beetles (Coleoptera: Carabidae) and spiders (Araneae) as bioindicators of sustainable forest management: A review. Ecological Indicators 6:780-793. doi: https://doi.org/10.1016/j.ecolind.2005.03.005.

R Development Core Team. 2013. R: A language and environment for statistical computing. $\mathrm{R}$ Foundation for Statistical Computing.
Restu IW. 2002. Kajian Pengembangan Wisata Mangrove di Taman Hutan Raya Ngurah Rai Wilayah Pesisir Selatan Bali. Tesis. Bogor: Institut Pertanian Bogor.

Riley KN, Browne RA. 2011. Changes in ground beetle (Coleoptera: Carabidae) diversity and community composition in age structured in Piedmont forests. ZooKeys 147:601-621. doi: https://doi.org/10.3897/zookeys.147.2102.

Schowalter TD. 2011. Insect Ecology: An Ecositem Approach. $3^{\text {th }}$ edition. Oxford: Elseveir.

Skalski T, Pośpiech N. 2006. Beetles community structures under different reclamation practices. European Journal of Soil Biology 42:316-320. doi: https://doi.org/10.1016/j. ejsobi.2006.07.026.

Speight MR, Hunder MD, Watt AD.2008. Ecology of Insect Concept and Applications. Oxford: BlackWell.

Susilo FX, Indriyati, Hardiwinoto S. 2009. Diversity and abundance of beetle (Coleoptera) functional groups in a range of land use system in Jambi, Sumatra. Biodiversitas 10:195-200. doi: https:// doi.org/10.13057/biodiv/d100406.

Wardle DA, Bardgett RD, Callaway RM, Van der Putten WH. 2011. Terrestrial ecosystem responses to spesies gains and losses. Science 332:1273-1277. doi: https://doi.org/10.1126/ science. 1197479 .

Webb NR, Clarke RT, Nicholas JT. 1984. Invertebrate diversity on fragmented CallunaHeathland: Effects of surrounding vegetation. Journal of Biogeography 11:41-46. doi: https:// doi.org/10.2307/2844774.

Young TP, Chase JM, Huddleston RT. 2001. Community succession and assembly: comparing, contrasting and combining paradigms in the context of ecological restoration. Ecological Restoration 19:5-18. doi: https://doi. org/10.3368/er.19.1.5. 